\title{
Determination of Soil, Litter Properties and Carbon Stock Capacities of Different Stand Types in Western Black Sea Region
}

\author{
Elsedeg Hagi Almansouri \\ Faculty of Forestry, Kastamonu University, Turkey \\ E-mail: sadek.h1961@gmail.com.tr \\ Mirac Aydin \\ Faculty of Forestry, Kastamonu University, Turkey \\ E-mail: maydin@kastamonu.edu.tr \\ Senem Gunes Sen (Corresponding author) \\ Faculty of Forestry, Kastamonu University, Turkey \\ E-mail: sgunes@kastamonu.edu.tr
}

\begin{abstract}
The aim of the study is to reveal how some of the physical and chemical properties of the soil and litters in the Pinus nigra, Pinus sylvestris and Pinus sylvestris-Pinus nigra stand mixture and how the amount of carbon stored varies according to the tree type. In this context, soil samples were collected from two different levels, litter examples were collected from two different layers including leaf and fermentation+humus and undisturbed soil samples were collected from three different depths. $\mathrm{pH}$, electrical conductivity, organic matter, texture, bulk density, carbon rate and carbon content values were determined in soil and litter samples.

According to the soil samples analysis results, the highest ph (7.74), electrical conductivity (147.85 $\mu \mathrm{s} / \mathrm{cm})$, organic matter $(3.03 \%)$, carbon ratio (1.76\%), carbon amount $(6.72 \mathrm{t} / \mathrm{ha})$, clay $(24.81 \%)$ and silt $(11.49 \%)$ values were determined in Pinus sylvestris-Pinus nigra stand mixtures. The highest sand value $(73,60 \%)$ in Pinus sylvestris and bulk density value $\left(1.42 \mathrm{gr} / \mathrm{cm}^{3}\right)$ in Pinus nigra has been identified. The average values of $\mathrm{pH}(6.93)$ and carbon ratio $(30.38 \%)$ in litter samples were determined in the highest Pinus sylvestris-Pinus nigra stand mixtures. According to the statistical analysis, it was determined that there was no statistically significant difference $(p>0.05)$ in carbon amount, dust ratio and bulk density values in soil samples. In other analyzes, it was determined that there were significant differences between the groups $(\mathrm{p}<0.05)$. According to the results of the analysis of $\mathrm{pH}$ and carbon ratio in litter samples, there was no significant difference between the groups ( $\mathrm{p}>$ $0.05)$.
\end{abstract}

Key Words: Litter, Soil, Carbon, Pinus sylvestris, Pinus nigra, Mixture stand

DOI: $10.7176 / \mathrm{JSTR} / 6-12-06$

\section{Introduction}

The increase in the amount of fossil fuel consumption and the change in land use from human activities in the insiltrial age caused a significant increase in the concentration of greenhouse gasses in the atmosphere. The concentration of atmospheric carbon dioxide was around $280 \mathrm{ppm}$ prior to the insiltrial revolution, but increased to $379 \mathrm{ppm}$ as a result of measurements in 2005 . This concentration is reported to increase by $1.8 \mathrm{ppm}$ per year (IPCC, 2006). This increase also triggers global and regional climate change.

The Mediterranean Basin in which our country is located is extremely vulnerable to global climate change. With climate change, our country will experience unusual or more severe weather events in the Mediterranean basin, an increase in forest fires, a decrease in biodiversity, loss of soil yields,

$\mathbf{5 1} \mid \mathrm{P}$ a g e

www.iiste.org 
desertification and, perhaps most importantly, drought. The National Action Plan on Climate Change (IDUEP, 2011) states that temperatures in our country will increase between $2.5{ }^{\circ} \mathrm{C}$ and $4{ }^{\circ} \mathrm{C}$, and this increase will also reach $5{ }^{\circ} \mathrm{C}$ in the inland and terrestrial regions of the country. As a result, the country is expected to have a climate type with warmer, arid and irregular rainfall potential in the future (URL 2).

The amount of plant bio-mass and carbon stock in the soil in our forests, which is $27 \%$ of the total area of Turkey, must be determined.

In total, there are five large global carbon pools (oils, soil, atmosphere, plant biomass and coal, gas and oil stored in the Earth's sphere) (Lal, 2004). Although plant bio-mass has the smallest value in carbon pools, it has a very important place in the carbon stock. Significant increases in atmospheric carbon concentrations are observed due to vegetation destruction or land use change as vegetation is a sensitive and rapidly variable carbon stock. Plants, as is known, absorb and photosynthesize atmospheric $\mathrm{CO} 2$ and store it as a bio-mass in their structures. Carbon is stored in soil as a result of dead plants or dead plant material mixing with soil (Tomlinson, 2005). Forests account for about $80 \%$ of the pool of vegetable carbon (Dixon et al., 1994; Laganière et al., 2010). Forest soils, on the other hand, contain about 70\% of the carbon stored in forest ecosystems (Dixon et al., 1994; Six t al., 2002). Organic carbon composed of vegetation components can be stored in the soil under appropriate conditions for many years (von Lutzow et al., 2006). In addition, soils are the best environments for storing carbon in terrestrial ecosystems and provide low cost opportunities. Therefore, the storage of atmospheric carbon in soils has attracted a great interest in the scientific world in recent years (Johnson 1992; Nave et al. 2010; Deluca and Boisvenue 2012).Organic material or carbon in the soil is also important for the health, productivity and nutrient cycle of the soil. In addition to the positive effects that the carbon stored in the soil will have on the earth, it also provides carbon credits to the countries in which it is located. It is therefore necessary to store and maintain the organic carbon that is abundant in the structure of the organic material in the forest, to ensure its continuity and to well-manage the organic matter of the soil (Marland et al., 2001). Studies to be carried out for this purpose will also contribute to the development of a sustainable soil and environmental environment.

In order to determine the carbon storage quantities of forests in our country, annual carbon stocks of topsoil and subsoil plant biomass of forest ecosystems in our country were determined using the National Forest Inventory completed in 2004 and according to the gain-loss method in Guide "Agriculture, Forestry and Other Land Use (AFOLU)" published in 2006 (Tolunay, 2011). According to 2004 data, the total carbon stock in our forests is $2251,26 \mathrm{Tg}(1 \mathrm{Tg}=1.0 \times 1012)$, of which $74.78 \%$ is stored in soil, $21.32 \%$ is stored in topsoil biomass and $3.90 \%$ is stored in litter. Various studies have shown that differences in tree species are an important factor affecting changes in carbon storage capacity (Conen et al. 2006).

The most commonly used and bulk-based method for determining the carbon stored in the soil is the value found by multiplying the percentage of organic carbon by the bulk density of the soil, the depth of which is known (Markewitz et al., 2002; Sartori et al ark., 2007; Mao et al., 2010).

The aim of this study was to determine the amount of carbon stored in the soil and litter using a bulkbased method in the Pinus nigra, Pinus sylvestris and Pinus sylvestris-Pinus nigra stand mixtures located within the Kastamonu Forest Management Department of the Kastamonu Forest Regional Directorate and to contribute to the literature in this regard.

In addition to the diversity of forest tree composition within the boundaries of the Kastamonu Forest Management Department, which is affiliated with the Kastamonu Forest Regional Directorate, and the fact that such studies have not been carried out in these areas has been one of the beginning points of this study.

\section{Study area}

The forest areas within the borders of Kastamonu Forest Management Department (Figure 1) in Kastamonu province in the Western Black Sea region of Turkey constitute the study area. The borders of Kastamonu Forest Management Department are located between the northern latitudes of $41^{\circ} 18^{\prime} 14^{\prime \prime}$ - 41 $28^{\prime} 55^{\prime \prime}$ and the Eastern longitudes of $33^{\circ} 32^{\prime} 08^{\prime \prime}-33^{\circ} 36^{\prime} 55^{\prime \prime}$. The altitude of the land starts from $756 \mathrm{~m}$ altitude and rises up to $1512 \mathrm{~m}$ altitude. 

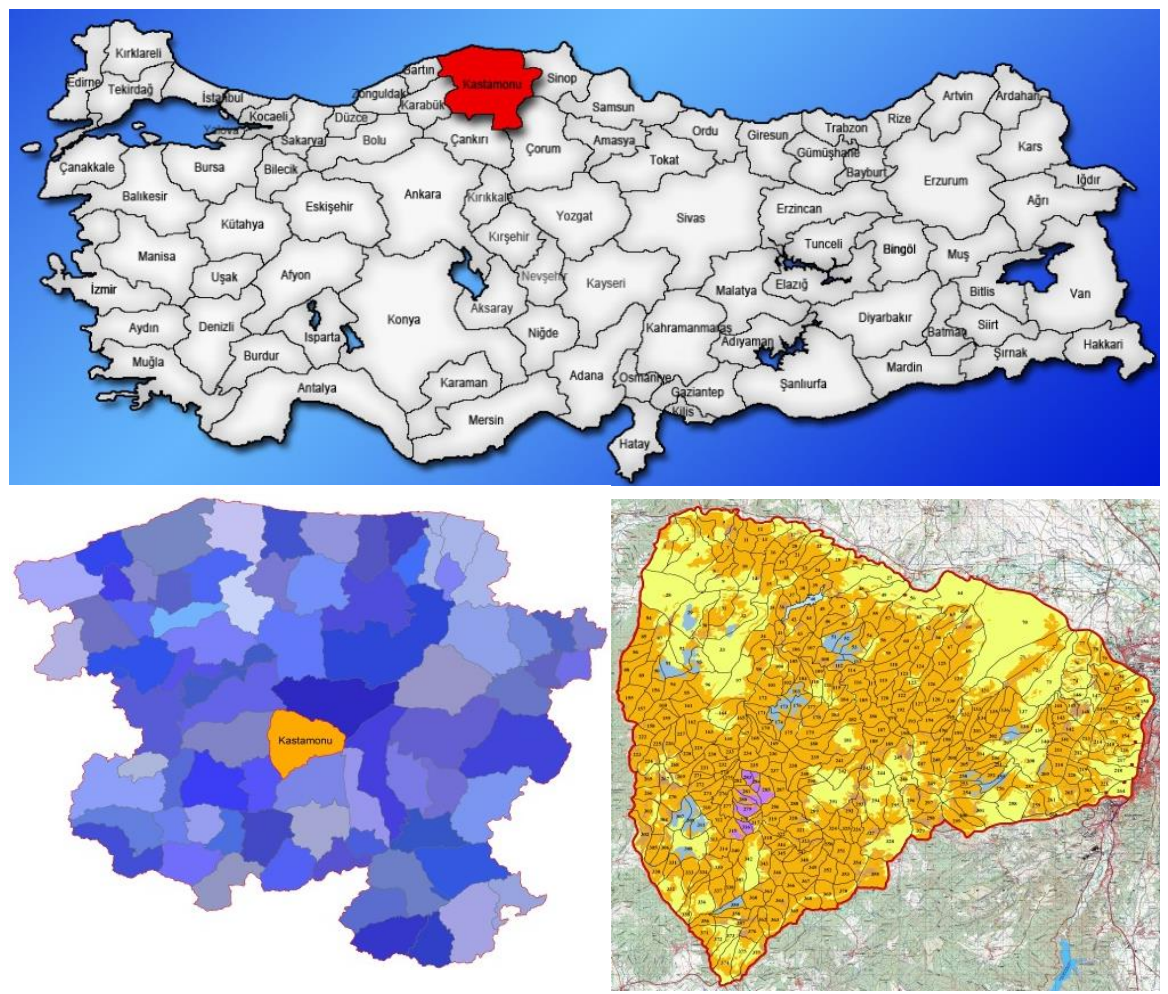

Figure 1. Location of the study area

When the geological and minerological structure of Kastamonu Forest Management Department is examined, the Eocene formation in the limestone facies of the Department area near the city center of Kastamonu has generally developed in the flis facies or volcanic facies. The sections of the Kastamonu Highway close to Kastamonu are included in this union in mesozoic (ophiolitic serie), mostly cretaceous (Mof), fine granular Litakels, spilite, diabase, basalt and andesite species, amygdaloid and pillow-shaped undersea lavas, as well as in blocks of white-gray and mostly massive limestone. In the eastern sections, the Metaformic series are continuous and large massifs (Anonymous, 2014).

The total area of the Department is $24.353,4$ hectares, of which $16.649,9$ hectares consist of forested lands (Anonymous, 2014).

The average annual rainfall of the study area is $481.9 \mathrm{~mm}$ and the average annual temperature is $9.8^{\circ} \mathrm{C}$. According to the water balance generated by the Thornthwaite method of the area the climate type is determined as C1 B'1 s b'3 (Semi-arid - less humid, 1st Degree mesothermal, water surplus in winter and moderate, summer evaporation rate: $54.8 \%$ ) (URL-1).

\section{Material and methods}

\subsection{Materials}

The research material was determined within the boundaries of Kastamonu Forest Management Department. The original data obtained from the analysis results of the litter and soil samples taken from the test sites identified in Pinus nigra, Pinus sylvestris and Pinus sylvestris - Pinus nigra stand mixtures, which are close to each other and have similar characteristics.

The data in the study were obtained by analyzing the results of samples taken from the site in 2019 and calculations.

\subsection{Methods}

In order to determine the amount of carbon stored in soils and litters under different types of forest trees from the Department's stand map, it is based on similar effects in forest ecosystems other than the stand type (Zengin, 1997). For this purpose, stands were determined the areas where the topographic and climatic factors and the properties of the stands were closest to each other. Attention has been paid to the selection of sample areas that are far from roads, pathways, human influence and have 
homogeneous and close geomorphological characteristics (to fix the climate factor) as ecological features. In this context, sample areas of Pinus nigra, Pinus sylvestris and Pinus sylvestris-Pinus nigra stand mixtures with the same density were selected in the village of Kurucaören for the main purpose of the study. The silvicultural characteristics of the selected stands are shown in Table 1. (Anonymous, 2014).

Table 1. Silvicultural characteristics of the study areas

\begin{tabular}{|l|l|l|}
\hline Tree Species & Type of Stand & Closure \% \\
\hline Pinus nigra & Çkbc2 & $41-70$ \\
\hline Pinus sylvestris & Çsbc2 & $41-70$ \\
\hline Pinus sylvestris-Pinus nigra & ÇsÇkc3-2 & $41-70$ \\
\hline
\end{tabular}

In the study, litter samples were collected using a 20x20 cm litter sampling frame to determine the amount of carbon stored in the litter accumulated under different tree species. The Leaf, Fermentation and Humus layers were taken as two separate layers, Leaf (L) and Fermentation+Humus (H), instead of three separate layers due to the difficulty of layer separation in the litter samples and to avoid deterioration in their natural structure. A total of 60 litter samples, including 20 from each test area, were taken and it was taken into account that the litter did not mix with the mineral soil.

From the point where the litter samples were taken, a total of 90 undisturbed soil samples were taken with the bulk cylinders $(5 \mathrm{~cm}$ in diameter and $5 \mathrm{~cm}$ in length), including 30 from each test area from three different depth stages $(0-5 \mathrm{~cm}, 5-10 \mathrm{~cm}$ ve $10-15 \mathrm{~cm})$ to determine the bulk density. When collecting the soil bulk samples with bulk cylinders, care was taken not to compress the soil in the cylinder and not to disturb the soil structure during tacking (Brown and Lugo, 1990; Armolaitis et al., 2013). After the cylinders were hammered to the desired depth, the edges and base were cleaned from the excess with a sharp knife and placed in polyethylene bags and brought to the laboratory for analysis.

In addition, 60 disturbed soil samples were taken from the close points where the litter sample was taken, 10 points from each stand from two different depth levels $(0-10 \mathrm{~cm}$ and $10-20 \mathrm{~cm})$, in order to determine some physical characteristics of stand soils.

Soil and litter samples were turned into air-dry soil and then sieved and made ready for analysis (Mubyana-John and Masamba, 2014).

In laboratory analyses, texture analysis, bulk density, amount of organic matter, $\mathrm{pH}$, electrical conductivity, carbon rate and carbon content of soils were determined. $\mathrm{PH}$ and carbon rate were determined in the litter samples. The Bouyoucos hydrometer method (Bouyoucos, 1936) was applied for texture analysis of soils. The bulk density is calculated as the weight of the soil in a specific volume cylinder sample, the natural structure of which is intact, which can accommodate a hollow structure (Irmak, 1954). Organic matter contents of soils were determined by the Walkley-Black method (Walkley and Black, 1934). Soil reactions $(\mathrm{pH})$ and electrical conductivity (EC) values were determined by preparing at the rate of 1/2.5 soil / pure water solution (Irmak, 1954; Ozyuvaci, 1971; Gulcur, 1974, Eruz, 1979). Litter/pure water solution was prepared and measured at the rate of 1/20 rate for the reactions of litter samples (Karaoz, 1992).

Walkley-Black method was used to determine the carbon rate in litter and soil samples and was calculated using conversion coefficients. The total amount of carbon is calculated by multiplying by bulk density, percentage of carbon rate and sample depth (cm) (Guo, Gifford,2002).

Statistical tests were carried out to determine whether there were any differences between the stand groups in terms of the variables analyzed. One-way ANOVA has been used to compare multiple groups. The differences between the species were determined and grouped according to the Duncan test. All statistical analyses were conducted with SPSS 20.0 program.

\section{Result and discussion}

The results of the analysis of soil and litter samples taken from the test areas are given in Table 2 . 
Table 2. Analysis results of soil and litter samples and statistical analysis results (ns: no significant difference $*: p<0.05$; significant difference )

\begin{tabular}{|c|c|c|c|c|c|}
\hline \multicolumn{2}{|c|}{ Soil Properties } & Pinus sylvestris & Pinus & $\operatorname{mix}$ & $\mathrm{p}$ \\
\hline \multirow{3}{*}{$\mathrm{pH}$} & $0-10 \mathrm{~cm}$ & 5,53 & 6,84 & 7,64 & \multirow{3}{*}{$0,000^{*}(1-2-3)$} \\
\hline & $10-20 \mathrm{~cm}$ & 5,65 & 7,04 & 7,84 & \\
\hline & Avarege & 5,59 & 6,94 & 7,74 & \\
\hline \multirow{3}{*}{$\mathrm{EC}(\mu \mathrm{s} / \mathrm{cm})$} & $0-10 \mathrm{~cm}$ & 71,59 & 113,37 & 146,52 & \multirow{3}{*}{$0,000^{*}(1-2-3)$} \\
\hline & $10-20 \mathrm{~cm}$ & 58,50 & 122,12 & 149,17 & \\
\hline & Avarege & 65,04 & 117,75 & 147,85 & \\
\hline \multirow{3}{*}{$\begin{array}{c}\text { organic matter } \\
(\%)\end{array}$} & $0-10 \mathrm{~cm}$ & 2,38 & 2,29 & 3,16 & \multirow{3}{*}{$0,034^{*}(1-3)$} \\
\hline & $10-20 \mathrm{~cm}$ & 2,41 & 2,18 & 2,89 & \\
\hline & Avarege & 2,39 & 2,23 & 3,03 & \\
\hline \multirow{3}{*}{$\begin{array}{c}\text { carbon rate } \\
(\%)\end{array}$} & $0-10 \mathrm{~cm}$ & 1,39 & 1,33 & 1,83 & \multirow{3}{*}{$0,038^{*}(3-1)$} \\
\hline & $10-20 \mathrm{~cm}$ & 1,44 & 1,26 & 1,68 & \\
\hline & Avarege & 1,42 & 1,30 & 1,76 & \\
\hline \multirow{3}{*}{$\begin{array}{l}\text { carbon content } \\
\quad(\text { ton/ha) }\end{array}$} & $0-10 \mathrm{~cm}$ & 5,56 & 5,15 & 7,12 & \multirow{3}{*}{$0,051^{\mathrm{ns}}$} \\
\hline & $10-20 \mathrm{~cm}$ & 5,90 & 4,78 & 6,32 & \\
\hline & Avarege & 5,73 & 4,97 & 6,72 & \\
\hline \multirow{3}{*}{ sand $(\%)$} & $0-10 \mathrm{~cm}$ & 72,88 & 67,96 & 65,42 & \multirow{3}{*}{$0,000^{*}(1-2-3)$} \\
\hline & $10-20 \mathrm{~cm}$ & 74,32 & 67,15 & 61,98 & \\
\hline & Avarege & 73,60 & 67,56 & 63,70 & \\
\hline \multirow{3}{*}{ clay $(\%)$} & $0-10 \mathrm{~cm}$ & 16,24 & 20,99 & 23,93 & \multirow{3}{*}{$0,000^{*}(1-2-3)$} \\
\hline & $10-20 \mathrm{~cm}$ & 16,20 & 21,53 & 25,69 & \\
\hline & Avarege & 16,22 & 21,26 & 24,81 & \\
\hline \multirow{3}{*}{ silt (\%) } & $0-10 \mathrm{~cm}$ & 10,87 & 11,05 & 10,65 & \multirow{3}{*}{$0,092^{\mathrm{ns}}$} \\
\hline & $10-20 \mathrm{~cm}$ & 9,48 & 11,32 & 12,33 & \\
\hline & Avarege & 10,18 & 11,19 & 11,49 & \\
\hline \multirow{4}{*}{$\begin{array}{l}\text { bulk density } \\
\qquad\left(\mathrm{gr} / \mathrm{cm}^{3}\right)\end{array}$} & $0-5 \mathrm{~cm}$ & 1,27 & 1,38 & 1,27 & \multirow{4}{*}{$0,724^{\mathrm{ns}}$} \\
\hline & $5-10 \mathrm{~cm}$ & 1,30 & 1,45 & 1,40 & \\
\hline & $10-15 \mathrm{~cm}$ & 1,40 & 1,44 & 1,39 & \\
\hline & Avarege & 1,32 & 1,42 & 1,35 & \\
\hline \multirow{3}{*}{$\mathrm{pH}$} & $\mathrm{L}$ & 6,87 & 6,83 & 6,92 & \multirow{3}{*}{$0,793^{\mathrm{ns}}$} \\
\hline & $\mathrm{H}$ & 6,80 & 6,97 & 6,94 & \\
\hline & Avarege & 6,83 & 6,90 & 6,93 & \\
\hline \multirow{3}{*}{$\begin{array}{c}\text { Carbon rate } \\
(\%)\end{array}$} & $\mathrm{L}$ & 30,73 & 30,59 & 29,90 & \multirow{3}{*}{$0,635^{\mathrm{ns}}$} \\
\hline & $\mathrm{H}$ & 28,19 & 29,35 & 30,86 & \\
\hline & Avarege & 29,46 & 29,97 & 30,38 & \\
\hline
\end{tabular}

When we examine the values in the table, it is seen that the $\mathrm{pH}$ values in soil samples take values close to each other in the topsoil and subsoil levels and that the highest value in the stands is the mixed stand. Average $\mathrm{pH}$ was found to be 5.59 in Pinus sylvestris, 6.94 in Pinus nigra and 7.74 in stand mixture. It was determined that there was a significant difference between $\mathrm{pH}$ mean values as a result of variance 
analysis of $\mathrm{pH}$ values $(\mathrm{P}<0,05)$. There are many studies in which different tree species in similar growing environments influence soil reactions (Diaz-Ravina et al. 1995; Mahia et al. 2006; Devi and Yadava 2006; Tian et al. 2008, Kara and Bolat, 2008a, Satti et al., 2003, Yang et al., 2010, Bolat, 2011, Aydin et al., 2018). Soil reactions are very important for the intake of plant nutrients. The $\mathrm{pH}$ values between 5.5 and 6.5 are the most ideal values, according to the data obtained from the studies on optimal soil reaction of forest trees (Cepel 1995).

Average electrical conductivity (EC) values in soil samples were found in stand mixtures of the highest $147.85 \mu \mathrm{s} / \mathrm{cm}$ and Pinus sylvestris of the lowest $65.04 \mu \mathrm{s} / \mathrm{cm}$. The Pinus nigra was determined to be $117.75 \mu \mathrm{s} / \mathrm{cm}$. As a result of variance analysis of the EC values of the soils in the study sites, it was determined that there was a significant difference between the average EC values $(\mathrm{P}<0,05)$. In studies to evaluate the EC value in soils of stands consisting of different species, it has been found that, usually in coniferous stands, the EC value is higher than the leafy species due to the higher cation content in the conifers of these species and the faster the free cation is mixed into the soil (Bolat, 2011, Kara et al. 2008, Aydın et al., 2018, Babur, 2018). The main source of salinity in soils is the mineral composition that forms bedrock. Soils are classified as saline soils if they exceed the amount of salinity set as a threshold value of $4000 \mu \mathrm{s} / \mathrm{m}$ (Sumner 1995). The fact that the study area data is well below this threshold indicates that there is no problem with salinity.

The average amount of organic matter in the soil of the research area was $2.39 \%$ in Pinus sylvestris and $2.23 \%$ in Pinus nigra and $3.03 \%$ in stand mixture. It was determined that there were significant differences between average organic matter contents $(\mathrm{p}<0,05)$. According to the Duncan test conducted to identify different groups, there was a difference between Pinus sylvestris and stand mixture. According to the results of similar studies, the value of organic matter in Pinus nigra, Fagus sylvatica and Abies nordmanniana was found to be $25.9 \%-32.1 \%-41.4 \%$ respectively and and Pinus nigra, Pinus sylvestris and Pinus sylvestris - Pinus nigra stand mixtures was found to be \%47,8 - \%32,1 \%30,2 respectively (Güneş Şen, 2015).

The average amount of sand in soil samples was found to be $73.60 \%$ in Pinus sylvestris and $67.56 \%$ in stand mixture; the average amount of clay was $21.26 \%$ in Pinus sylvestris and $24.81 \%$ in stand mixture; the average amount of silt was $11.19 \%$ in Pinus sylvestris and $11.49 \%$ in mixed stand mixture. In the analysis of variance based on sand, clay and silt amounts, it was determined that there was a significant difference between the soils in terms of sand and clay amounts $(\mathrm{p}<0.05)$ and that there was no significant difference in the amount of silt $(\mathrm{p}>0.05)$. Examining the results of similar studies the following results were obtained: sand was $56.7 \%$, silt $24.1 \%$ and clay $19.2 \%$ in Quercus pontica stand and sand $64.4 \%$, silt $19.8 \%$ and clay $15.8 \%$ in in Abies nordmanniana-Fagus sylvatica stand mixture (Kara et al., 2008); sand 23.17\%, silt 39.55\% and clay 37.28\% in Fagus sylvatica stand; sand $19.30 \%$, silt $20.10 \%$ and clay $60.60 \%$ in Pinus nigra stand (Kara et al., 2008a), the amount of sand in the Abies nordmanniana stand is $23.2 \%$, in the Fagus sylvatica stand is $24.1 \%$ and in the Abies nordmannianaFagus sylvatica stand mixture is $24.7 \%$; the amount of silt in the Abies nordmanniana stand is $21.3 \%$, in the Fagus sylvatica stand is $\% 27,1$ and in the Abies nordmanniana-Fagus sylvatica stand mixture is $24.9 \%$; the amount of clay in the Abies nordmanniana stand is $55.5 \%$, in the Fagus sylvatica stand is 48.8\% and in the Abies nordmanniana-Fagus sylvatica stand mixture is 50.4\% (Bolat, 2011), the amount of sand was $23.17 \%$ in forest area, $22.64 \%$ in pasture area, $15.70 \%$ in agricultural area; the amount of silt was $39.54 \%$ in forest area, $33.67 \%$ in pasture area, $22.45 \%$ in agricultural area; the amount of clay was $37.27 \%$ in forest area, $43.68 \%$ in pasture area, $61.84 \%$ in agricultural area (Bolat, 2007), the amount of sand was $68.5 \%-72.4 \%$ in Pinus nigra, $68.5 \%$ in Fagus sylvatica, $62.4 \%$ in Abies nordmanniana, $73.8 \%$ in Pinus sylvestris, $62.4 \%$ in Pinus sylvestris - Pinus nigra stand mixtures; the amount of clay was $8.9 \%-3.6 \%$ in Pinus nigra, $12.4 \%$ in Fagus sylvatica, $15.4 \%$ in Abies nordmanniana, $7.0 \%$ in Pinus sylvestris, $3.9 \%$ in Pinus sylvestris - Pinus nigra stand mixtures; the amount of silt was 22.6\%-22.0\% in Pinus nigra, $19.1 \%$ in Fagus sylvatica, $22.1 \%$ in Abies nordmanniana, $19.5 \%$ in Pinus sylvestris, $33.6 \%$ in Pinus sylvestris - Pinus nigra stand mixtures (Gunes Sen, 2015).

The average bulk density values of stand soils consisting of different species were determined as 1.32 $\mathrm{gr} / \mathrm{cm}^{3}$ in Pinus sylvestris and $1.42 \mathrm{gr} / \mathrm{cm}^{3}$ in Pinus nigra and $1.35 \mathrm{gr} / \mathrm{cm}^{3}$ in Pinus sylvestris - Pinus nigra stand mixtures. It was determined that there was no statistically significant difference in the bulk density values of soils belonging to different types of stands $(p>0.05)$. When we examine the values in Table 2 , it is observed that the lowest bulk density values are in the topsoil layers $(0-5 \mathrm{~cm})$. According to studies on this subject, some factors such as root density, organic matter content, stonyness and soil texture in the topsoils significantly affect the bulk density (Kantarc1, 2000). Examining the results of

56 | P a g e

www.iiste.org 
similar studies the following results of bulk density were obtained: $1.02 \mathrm{gr} / \mathrm{cm}^{3}$ in Abies nordmanniana, $1.04 \mathrm{gr} / \mathrm{cm}^{3}$ in Fagus sylvatica, $1.09 \mathrm{gr} / \mathrm{cm}^{3}$ in Abies nordmanniana-Fagus sylvatica stand mixture (Senturk, 2009); $1,0 \mathrm{gr} / \mathrm{cm}^{3}$ in forested areas, $1,6 \mathrm{gr} / \mathrm{cm}^{3}$ in agricultural areas (Williams et al., (2003); $0.86 \mathrm{gr} / \mathrm{cm}^{3}$ in mixed forest, $0.88 \mathrm{gr} / \mathrm{cm}^{3}$ in plantation, $1.02 \mathrm{gr} / \mathrm{cm}^{3}$ in pasture areas, 1.23 $\mathrm{gr} / \mathrm{cm}^{3}$ in agricultural areas (Patel et al., (2010); Quercus pontica ranges from $1.38 \mathrm{gr} / \mathrm{cm}^{3}$ to 1.46 $\mathrm{gr} / \mathrm{cm}^{3}$ (Devi et al., (2006); in subtropical forests it ranges from $1.3 \mathrm{gr} / \mathrm{cm}^{3}$ to $1.4 \mathrm{gr} / \mathrm{cm}^{3}$ (Maithani et al., (1998); 1,03 gr/ $\mathrm{cm}^{3}$ in Abies nordmanniana, 1,19 gr/ cm3 in Fagus sylvatica, $1,18 \mathrm{gr} / \mathrm{cm}^{3}$ in Abies nordmanniana-Fagus sylvatica stand mixture (Bolat, 2011); 0,90 gr/ $\mathrm{cm}^{3}$ in Fagus sylvatica, 0,99 gr/ $\mathrm{cm}^{3}$ in Cedrus libani and 1,12 $\mathrm{gr} / \mathrm{cm}^{3}$ in Pinus nigra (Babur, 2018). According to the results obtained from the study, it was revealed that different types of stands can have an effect on the bulk density of soils. According to analysis of soil samples, the carbon rate was $1.42 \%$ in Pinus sylvestris and $1.30 \%$ in Pinus nigra and $1.76 \%$ in Pinus sylvestris - Pinus nigra stand mixtures and the total amount of carbon was determined as 5.73 tons/ha in the Pinus sylvestris and 4.97 tons/ha in the Pinus nigra and 6.72 tons/ha in the Pinus sylvestris - Pinus nigra stand mixtures. In the analysis of variance based on carbon rates and carbon contents, it was determined that there was a significant difference between the soils in terms of carbon rate $(\mathrm{p}<0.05)$ and there was no significant difference in the total carbon content $(p>0.05)$. Similar studies also show that these rates are as follows: $8 \%$ in spring season in Abies nordmanniana stand, $1.2 \%$ in summer season in Abies nordmanniana-Fagus sylvatica stand (Bolat, 2011); between 6.5\%-10.3\% in Abies nordmanniana in Uludag according to the elevation (Kantarc1, 2000), 3.85\% in Quercus pontica stand and 5.96\% in Abies nordmanniana -Fagus sylvatica mixture stand (Kara et al., 2008); 4.14\% in Fagus sylvatica stand, $2.51 \%$ in Pinus nigra stand (Kara et al., 2008a); $4.29 \%$ in Fagus sylvatica stand, 6,09\% in Abies nordmanniana stand, 4.51\% in Abies nordmanniana -Fagus sylvatica mixture stand (Senturk, 2009); between $5.23 \%-7.81 \%$ and $8.03 \%$ $12.07 \%$ in Fagus sylvatica forest, between $4.42 \%-7.70 \%$ and $6.84 \%-9.77 \%$ in Quercus pontica Forest, between $4.02 \%-6.19 \%$ and $7.24 \%-9.59 \%$ in Pinus nigra forest (Kara, 2002); between $2.75 \%$ $4.40 \%$ and $2.60 \%-4.34 \%$ in mixed Quercus pontica stands (Devi et al., 2006); between $8.5 \%-2.6 \%$ in Pinus pinaster forests (Diaz-Ravina et al., 1995); 3.85\% in bamboo plantation (Upadhyaya et al., 2004); $6.63 \%$ in mixed pine forests and $7.78 \%$ in pasture areas (Chen et al., 2003); $1.1 \%$ in bottom land with mixed forests and $1.4 \%$ isin mountainous terrain (Chen et al., 2005); between $1.79 \%-9.00 \%$ in mixed forest areas consisting of quercus, pinus, populus, ulmus and carpinus species (Tian et al., 2008); between $3.9 \%$ and $13.8 \%$ in Pinus pinaster forests, between $4.3 \%-16.2 \%$ in Pinus sylvestris forests (Mahia et al., 2006); between 3.6\%-6.2\% in subtropical forests (Maithani et al.,1996); 2.39\% in mixed forests with pinus, quercus and eucalyptus species (Alvarez et al., 2009); between $2.36 \%$ and $4.28 \%$ in forest areas, between $2.24 \%$ and $3.78 \%$ in plantation area, between $1.81 \%$ and $3.42 \%$ in pasture area, between $1.35 \%$ and $2.53 \%$ in agricultural area (Patel et al., 2010); between $4.0 \%-7.4 \%$ in three different types of conifers, $5.4 \%-10.8 \%$ in three different types of evergreen broadleaf, $7.4 \%-14.2 \%$ in four different types of non-evergreen species (Satti et al., 2003). In forest ecosystems, the surface of the soil is often covered with cones, thin branches, bark, leaves and organism residues. These dead plant residues, soil organisms and plant roots make up the source of organic matter in forest soils. Soil organic carbon is released as a result of the decomposition of all these residues by living things. According to Plaster (1992), there are four main factors that directly affect the amount of organic matter in the soil or the amount of organic carbon. These factors are listed primarily as vegetation, climate, soil texture and soil processing. In addition, the composition of the litter (lignin, cellulose, hemicellulose, etc.) affects decomposition, so the amount of organic carbon of the soils also varies. For example, as the amount of lignin increases in the litter, the rate of decomposition of the conifer and leaves slows down (Cakiroglu 2011). Although the areas in which the study was conducted were in approximately the same habitat (climatic, edaphic and physiographic), the amount of carbon in the stand was affected by stand types. In other words, organic carbon has changed depending on the species composition of stands. The organic carbon content values obtained from the study are similar to the studies conducted by various researchers in different fields.

The average $\mathrm{pH}$ values of the litter samples were found to be 6.93 in Pinus sylvestris and 6.97 in Pinus nigra and 6.93 in mixture stand. It was determined that there was no significant difference between average $\mathrm{pH}$ values according to variance analysis $(\mathrm{p}>0.05)$. The reactions of forest trees litter residues are often different from each other. It is stated that acid products occur from the decomposition of dead coverings of some coniferous trees (Cepel, 1995; Kantarci, 2000). The $\mathrm{pH}$ values found according to the results of similar studies on this subject are as follows: $\mathrm{pH}$ of forrested area in lowland terrain is 4.18, $\mathrm{pH}$ of forested area in mountainous terrain is 4.20 (Chen et al., 2005); $\mathrm{pH}$ values in coniferous

$\mathbf{5 7} \mid \mathrm{P}$ a g e

www.iiste.org 
plantations are between 4.30-5.70 in leaf layer, 4.23-5.83 in fermentation layer, 4.27-5.77 in humus layer (Karaoz, 1991); 6,15 in Pinus nigra, 7,37 in Fagus sylvatica, 7,43 in Cedrus libani (Babur, 2018); 7,29 in Abies nordmanniana in winter season, 6,23 in summer season (Bolat, 2011). As a result of the research, it was determined that the differences observed in the litter reaction vary depending on the type of tree.

In the litter samples, the average carbon rate was found to be $29 \%$ in Pinus sylvestris, $29 \%$ in Pinus nigra and $30 \%$ in mixture stand. It was determined that there was no significant difference between the carbon content values of the litter according to the different types ( $p>0.05)$. When we examine other studies on this subject, it is observed that the carbon rate values are as follows: $11.4 \%$ in the spring season in Fagus sylvatica stand, 36.8\% in the spring season in Abies nordmanniana -Fagus sylvatica stand (Bolat, 2011); varies between 32.0\%-29.4\% in Abies nordmanniana of Uludag depending on the elevation (Kantarci, 2000); between 52.0\% and 52.5\% in L layer in Pinus nigra and between $48.4 \%$ and $51.8 \%$ in F layer (Chen et al., 2003), In Picea abies, carbon rate in organic humus layer is $26.6 \%$ in control area, $25.1 \%$ in lime area, $29.5 \%$ in acid irrigation area, 31.9\% in lime and acid irrigation, $27.1 \%$ in normal irrigation, 26.3\% in lime and normal irrigation (Anderson, 1998); 9.6\% in lowland land with mixed forests, $16.2 \%$ in mountainous terrain (Chen et al., 2005); 33.23\% in Pinus nigra, 32.67\% in Cedrus libani, 27.95\% in Fagus sylvatica (Babur, 2018); between $36.08 \%$ and $40.80 \%$ in 7 -year-old Pinus-Quercus mixed forests, between $37.30 \%$ and $47.60 \%$ in 13 -year-old mixed forest (Maithani et al., 1998). In the forest, the amount of organic carbon in the subsoil and topsoil litter layer varies according to tree type, stand type, density, temperature and humidity (Cepel, 1995). It also provides information about the amount of leaf/conifer casting and root mass of the plants, the organic carbon and nutrients imparted to the soil surface and soil, depending on the plant type (Tufekcioglu et al., 2005). Considering that organic material is a heterogeneous structure, approximately $50 \%$ of this material consists of organic carbon (Uzbek et al. 2001). It is thought that the reason why organic carbon data obtained in the field of research falls below this value is due to the adverse effects of growing environment conditions (physiographic, climatic and edaphic) on decomposition.

\section{Conclusion}

For the purposes of this study, different soil types covered by some physical and chemical properties of carbon storage capacity and litter have been identified, with some physical and chemical properties of soils having a significant effect on tree species diversity $(\mathrm{P}<0.05)$. Different types of trees that grow under similar ecological and geomorphological conditions in stand ecosystems have a different effect on the formation of forest litter and soils. The differences in the chemical structure of both the root structures of trees and the litters affect the decomposition products and duration, so the soil characteristics that show similar characteristics in the first place can often show different characteristics. It was determined that the carbon storage capacities of the litter and soils also have significant effects on the physical and chemical properties of the soil. It has been clearly presented that differences in tree species have statistically significant effects on soil properties.

The data obtained as a result of the study provide preliminary information on the soil characteristics of areas in a similar condition with the characteristics of the study area. In addition, in the years to come, studies will be carried out on a periodic basis, taking samples from the trial areas and determining how these areas will be affected by climate change. Thus, it is thought that long-term soil monitoring works will begin.

It is thought that in the case of forestry interventions taking into account the amount of carbon stored in litter and soil, the effects of the minimum cutting age and the production of wood on carbon retention can be assessed together and used as a basis for the preparation of mnagement plans.

Research has shown that tree species have an effect on the amount of carbon stored in soils. In line with this information, forestry activities may be directed by considering more carbon storage capacity in future afforestation studies. In addition, care should be taken to carry out activities that increase carbon storage in forests, along with production in management applications. A good understanding of the changes in the organic carbon stock of forest soil, which is one of the major carbon reserves, can play a more active role in the development of forest resource management strategies. For this reason, it is believed that this type of work should have an important place in forestry applications. 


\section{Acknowledgment}

This article was prepared using the data of the $\mathrm{PhD}$ thesis entitled "Determination of the Carbon Content of Litter and Soil in Different Types of Stands" which is being carried out at Kastamonu University Institute of Natural and Applied Sciences.

\section{References}

Alvarez, E,. Torrado, V.M., Fernandez, M.L. \& Diaz-Ravia, M., (2009). Microbial biomass and activity in a forest soil under different tree species. Electronic Journal of Environmental, Agricultural and Food Chemistry, 8 (9): 878-887

Anderson, T.H., (1998). The influence of acid irrigation and liming on the soil microbial biomass in a Norway Spruce (Picea abies (L.) K.) stand. Plant and Soil, 199: 117-122

Anonymous, (2014). Kastamonu Orman İşletme Şefliği, Ekosistem tabanlı fonksiyonel orman amenajman planı 2014-2033

Armolaitis, K., Kabasinskiene, I.V., Stupak, I., Kukkola, M., Miksys, V., \& Wojcik, J. (2013). Carbon and nutrients of scots pine stands on sandy soils in Lithuania in relation to bioenergy sustainability. Biomass and Bioenergy, 54, 250-259. doi:10.1016/j.biombioe.2013.03.034

Aydın, M., Güneş Şen, S., \& Celik, S. (2018). Throughfall, stemflow, and interception characteristics of coniferous forest ecosystems in the western black sea region of Turkey (Daday example). Environmental Monitoring And Assessment, 190(5), 316

Babur, E,. (2018). Karstik orman ekosistemlerinde aynı yaşlı karaçam, sedir ve kayın ormanlarının ölü örtü ve topraklarında depolanan karbon-azot miktarlarının belirlenmesi; bazı mikrobiyal özelliklerinin mevsimsel değişimlerinin izlenmesi, Kahramanmaraş Sütçü İmam Üniversitesi Fen Bilimleri Enstitüsü, Doktora Tezi

Bolat, İ., (2007). Farklı Arazi Kullanım Biçimlerinin Toprağın Mikrobiyal Biyokütle Karbon (Cmic) ve Azot (Nmic) İçeriğine Etkisi, Yüksek Lisans Tezi, Zonguldak Karaelmas Üniversitesi, Fen Bilimleri Enstitüsü, Zonguldak

Bolat, İ., (2011). Kayın, Göknar ve Göknar-Kayın Mescerelerinde Üst Toprak ve Ölü Örtüdeki Mikrobiyal Biyokütle Karbon (Cmic), Azot (Nmic), Fosfor (Pmic) ve Mikrobiyal Solunumun Mevsimsel Değişimi, Bartın Üniversitesi, Fen Bilimleri Enstitüsü.Doktora Tezi

Bouyoucos, G.J. (1936). Directions for making mechanical analysis of soils by the hydrometer method. Soil Science, 4: 225 - 228

Brown, S., \& Lugo, A.E., (1990). Effects of forest clearing and succession on the carbon and nitrogen content of soils in Puerto Rico and US Virgin Islands. Plant and Soil, 124(1), 53-64

Chen, C.R., Condron, L.M., Davis, M.R. \& Sherlock, R.R., (2003). Seasonal changes in soil phosphorus and associated microbial properties under adjacent grassland and forest in New Zealand. Forest Ecology and Management, 177: 539-557

Chen, T.H., Chiu, C.Y. \& Tian, G.L., (2005). Seasonal dynamics of soil microbial biomass in coastal sand dune forest. Pedobiologia, 49: 645-653

Conen, F., Leifeld, J., Seth, B. \& Alewell, C., (2006). Warming mineralises young and old soil carbon equally. Biogeosciences, 3:515-519 
Çakıroglu, K., (2011). Bartın İli Arıt Yöresindeki Kayın, Göknar ve Göknar-Kayın Mescerelerindeki Ölü Örtü Ayrısması Ve Yıllık Yaprak Dökülmesinin Arastırılması. Yüksek Lisans Tezi, BÜ Fen Bilimleri Enstitüsü, Orman Mühendisligi Anabilim Dalı, Bartın, 79

Çepel, N., (1995). Orman Ekolojisi. İÜ Toprak İlmi ve Ekoloji Anabilim Dalı, Üniversite Yayın No. 3886, Sosyal BMYO, Yayın No: 433, İstanbul, 536

Deluca, T.H. \& Boisvenue, C., (2012). Boreal forest soil carbon: distribution, function and modelling. Forestry: An International Journal of Forest Research, Volume 85, Issue 2, 1 April 2012, Pages 161-184

Devi, N.B., \& Yadava, P.S. (2006). Seasonal dynamics in soil microbial biomass C, N and P in a mixed-oak forest ecosystem of Manipur, North-east India. Applied Soil Ecology, 31: 220-227

Diaz-Ravina, M., Acea, M.J., \& Carballas, T. (1995). Seasonal changes in microbial biomassand nutrient flush in forest soils. Biology and Fertility of Soils, 19: 220-226

Dixon, R. K., Brown, S., Houghton, R. A., Solomon, A. M., Trexler, M. C., \& Wisniewski, J. (1994). Carbon pools and flux of global forest ecosystems. Science, 263(5144), 185-190. doi:101126/science.263.5144.185

Eruz, E. (1979). Toprak tuzlulugu ve bitkiler üzerindeki genel etkileri. İÜ Orman Fakültesi Dergisi, Seri B, 29 (2), 112-120

Guo, L. B., \& Gifford, R. M. (2002). Soil carbon stocks and land use change: a meta analysis. Global Change Biology, 8(4), 345-360

Gülçur, F., (1974). Topragın Fiziksel ve Kimyasal Analiz Metodları. Kutulmus Matbaası, İÜ Yayın No. 1970, Orman Fakültesi Yayın No. 201, İstanbul, 225

Güneş Şen, S. (2015). Kastamonu-Daday yöresinde farklı meşcere tiplerinde yağışın dizpozisyonu ve özellikleri. Kastamonu Üniversitesi Fen Bilimleri Enstitüsü, Yüksek lisans Tezi

IPCC, (2006). IPCC Guidelines for national greenhouse gas inventories, prepared by the national greenhouse gas inventories programme: Annex:2 Summary of Equations. http://www. ipccnggip. iges.or.jp/public/2006gl/pdf/4_Volume4/V4_14_An2_Sum (02/01/2016)

IDUEP, (2011). TC. İkim Değişikliği Ulusal Eylem Planı. Çevre ve Şehircilik Bakanlığı, Ankara

Irmak, A., (1954). Arazide ve Laboratuvarda Topragın Arastırılması Metodları. İÜ Yayın No. 559, Orman Fakültesi Yayın No. 27, İstanbul, 150

Johnson, D,W., (1992). Effects of Forest Management on Soil Carbon Storage. Water, Air, and Soil Pollution, 64: 83-120, 1992

Kantarcı, M.D., (2000). Toprak İlmi, İstanbul Üniversitesi Toprak İlmi ve Ekoloji Anabilim Dalı, İstanbul Üniversitesi Yayın No. 4261, Orman Fakültesi Yayın No. 462, İstanbul, 420

Karaöz, M.Ö., (1991). Atatürk Arboretumu'ndaki bazı igne yapraklı plantasyonlarda ölü örtünün kimyasal özellikleri üzerine arastırmalar. İÜ Orman Fakültesi Dergisi, Seri A, 41 (2), 69-86

Karaöz M.Ö., (1992). Yaprak ve Ölü Örtü Analiz Yöntemleri. İÜ Orman Fakültesi Dergisi,Seri B, 42 (1-2), 57-71. 
Kara, Ö., (2002). Kuzey Trakya Daglık Yetisme Ortamı Bölgesinde Kayın, Meşe ve Karaçam Ormanlarındaki Toprak Mikrofunguslarının Mevsimsel Degisimi, Doktora Tezi, İstanbul Üniversitesi Fen Bilimleri Enstitüsü, Orman Mühendisligi Anabilim Dalı, İstanbul, 140

Kara, Ö., Bolat, İ., Çakıroglu, K. \& Öztürk, M., (2008). Plant canopy effects on litter accumulation and soil microbial biomass in two temperate forests. Biology and Fertility of Soils, 45(2): 193198

Kara, Ö. \& Bolat, İ., (2008a). Soil microbial biomass $\mathrm{C}$ and $\mathrm{N}$ changes in relation to forest conversion in the northwestern Turkey. Land Degradation and Development, 19(4): 421-428

Lal, R., (2004). Soil carbon sequestration to mitigate climate change. Geoderma, 123:1

Laganiere, J., Angers, D. A., \& Pare, D., (2010). Carbon accumulation in agricultural soils after afforestation: a meta-analysis. Global Change Biology, 16(1), 439-453

Mahia, J., Perez Ventura, L., Cabaneiro, A. \& Diaz-Ravina, M., (2006). Soil microbial biomass under pine forest in the north-wester Spain: influence of stand age, site index and parent material. Investigaciones Agrarias: Sistemas Recursos Forestales, 15 (2):152-159

Maithani, K., Tripathi, R.S., Arunachalam, A. \& Pandey, H.N. (1996). Seasonal dynamics of microbial biomass $\mathrm{C}, \mathrm{N}$ and $\mathrm{P}$ during regrowth of a disturbed subtropical humid forest in northeast India. Applied Soil Ecology, 4: 31-37

Maithani, K., Arunachalam, A., Tripathi, R.S. \& Pandey, H.N. (1998). Influence of leaf litter quality on N mineralization in soils of subtropical humid forest regrowths. Biology and Fertility of Soils, 27: 44-50

Mao, R., Zeng, D.H., Hu, Y.L., Li, L.J. \& Yang, D., (2010). Soil organic carbon and nitrogen stocks in an age-sequence of poplar stands planted on marginal agricultural land in Northeast China. Plant Soil. 332: 277-287

Markewitz, D., Sartori, F. \& Craft, C., (2002). Soil change and carbon storage in longleaf pine stands planted on marginal agricultural lands. Ecology Applied. 12:1276-1285

Marland, G., McCarl, B.A. \& Schneider, U., (2001). Soil carbon: Policy and economics. Climate Change. 51:101-117

Mubyana-John, T., \& Masamba, W.R.L., (2014). Soil Microbial Biomass Carbon, Nitrogen and Sulphur as Affected By Different Land Uses in Seronga, Okavango Delta, Botswana. British Journal of Environment \& Climate Change, 3(4), 628-639

Nave, L.E., Vance, E.D., Swanston, C.W. \& Curtis, P.S., (2010). Harvest impacts on soil carbon storage in temperate forests. Forest Ecology Management. 259:857- 866. doi:10.1016/j.foreco.2009.12.009

Özbek, H., Kaya, Z., Gök, M. \& Kaptan, H., (2001). Toprak Bilimi. ÇÜ Ziraat Fakültesi Genel Yayın No 73, Ders Kitapları Yayın No A-16, 5. Baskı, Adana, 816

Özyuvacı, N., (1971). Topraklarda erozyon eğiliminin tespitinde kullanılan bazı önemli indeksler, İstanbul Teknik Üniversitesi, Orman Fakültesi Dergisi, B, 21, 1:190-207

Patel, K., Nirmal Kumar, J.I., Kumar, N.R. \& Kumar, B.R., (2010). Seasonal and temporal variation in soil microbial biomass $\mathrm{C}, \mathrm{N}$ and $\mathrm{P}$ in different types land uses of dry deciduous forest ecosystem of Udaipur, Rajasthan, Western India. Applied Ecology and Environmental Research, 8(4): $377-390$

$61 \mid \mathrm{P}$ a g e

www.iiste.org 
Plaster, E.J., (1992). Soil Science and Management. Second Edition. Delmar Publishers Inc., Albany, New York, USA, 514 pp

Sartori, F., Lal, R., Ebinger, M.H. \& Eaton, J.A., (2007). Changes in soil carbon and nutrient pools along a chronosequence of poplar plantations in the Columbia Plateau, Oregon, USA. Agriculture Ecosystem Environment. 122:325-339

Satti, P., Mazzarino, M.J., Gobbi, M., Funes, F., Roselli, L. \& Fernandez, H. (2003). Soil N dynamics in relation to leaf litter quality and soil fertility in north-western Patagonian forests. Journal of Ecology, 91: 173-181

Six, J., Conant, R. T., Paul, E. A., \& Paustian, K. (2002). Stabilization mechanisms of soil organic matter: implications for C-saturation of soils. Plant Soil, 241:155-176

Sumner, M.E., (1995). Sodic soils: new perspectives. In: Australian Sodic Soils: Distribution, Properties and Management, eds. R Naidu, ME Sumner and P Rengasamy, CSIRO, Melbourne, pp. $1-34$

Şentürk, M., (2009). Arıt yöresindeki kayın, göknar, göknar-kayın mesçerelerinin yaprak alan indeksi, ölü örtü ve bazı toprak özelliklerinin incelenmesi. Yüksek Lisans Tezi, Bartın Üniversitesi Fen Bilimleri Enstitüsü, Orman Mühendisligi Anabilim Dalı, Bartın, 79

Tian, Y., Haibara, K., Toda, H., Ding F, Liu Y \& Choi, D., (2008). Microbial biomass and activity along a natural $\mathrm{pH}$ gradient in forest soils in a karst region of the upper Yangtze River, China. Journal of Forest Research, 13: 205-214

Tomlinson, R.W., (2005). Soil carbon stocks and changes in the Republic of Ireland. Journal of Environmental Management. 76(1):77-93

Tolunay, D., (2011). Total carbon stock and carbon accumulation in living tree biomass in forest ecosystems of Turkey. Turkish Journal of Agriculture and Forestry, 35(3), 265-279

Tüfekçioğlu, A., Sarıyıldız, T., Güner, S., \& Küçük, M. (2005). Artvin Genya Dağı Doğu Ladini Meşcerelerinde Kök Kütlesi, yıllık İbre Dökümü ve Toprak Solunumu Miktarlarının Değişimleri. Ladin Sempozyumu, I. Cilt, 123-129, Trabzon

Upadhyaya, K., Arunachalam, K. \& Arunachalam, A., (2004). Microbial C, N and P in Soils of Phyllostachys bambusoides plantation and Pinus roxburghii forest in Arunachal Pradesh, India. Journal of Tropical Forest Science, 16(2): 260-264

Walkley, A. \& Black, I.A. (1934). An examination of Degtjareff method for determining soil organic matter, and proposed modification of the chromic acid tritation method. Soil Science, 37: $29-38$

Williams AG, Ternan JL, Fitzjohn C, Alba S \& Perezgonzalez A (2003) Soil moisture variability and land use in a temperate-humid environment. Land Degradation and Development, 12: 477484

von Lützow, M., Kögel-Knabner, I., Ekschmitt, K., Matzner, E., Guggenberger, G., Marschner, B. \& Flessa, H., (2006). Stabilization of organic matter in temperate soils: mechanisms and their relevance under different soil conditions - a review. European Journal of Soil Science. 57:426445

URL-1,https://www.mgm.gov.tr/iklim/iklim-siniflandirmalari.aspx?m=KASTAMONU (06.08.2020) 
URL-2,_https://www.wwf.org.tr/ne_yapiyoruz/iklim_degisikligi_ve_enerji/iklim_degisikligi/kuresel iklim_degisikligi_ve_turkiye/_(04.09.2020)

Yang, K., Zhu, J., Zhang, M., Yan, Q. \& Sun, O.J., (2010). Soil microbial biomass carbon and nitrogen in forest ecosystems of Northeast China: a comparison between natural secondary forest and larch plantation. Journal of Plant Ecology, 3(3): 175-182.

Zengin, M. (1997). Comparison of Forest Ecosystems in Kocaeli Region in terms of hydrological Reforestations. Poplar and Fast Growing Forest Trees Research Institute, 182/275, Izmit, (06/08/2017) http://yayin.ogm.gov.tr/yaydepo/596.pdf 